\author{
Ewa Dzięgiel \\ Instytut Języka Polskiego Polskiej Akademii Nauk, Kraków \\ Uniwersytet Kardynała Stefana Wyszyńskiego, Warszawa \\ edziegiel5@gmail.com
}

\title{
ODMIANY TERYTORIALNE I SPOŁECZNE WSPÓŁCZESNEGO JĘZYKA POLSKIEGO NA UKRAINIE
}

Słowa kucze: mniejszość polska na Ukrainie, język polski na Ukrainie, polsko-ukraińskie kontakty językowe

Keywords: Polish minority in Ukraine, Polish language in Ukraine, Polish-Ukrainian language contacts

Zróżnicowanie współczesnego języka polskiego na Ukrainie świadczy o trwającym wiele stuleci i wielotorowym procesie kształtowania się skupisk mniejszości polskiej na tych ziemiach.

\section{Zróżnicowanie terytorialne}

Na sytuację języka polskiego na Ukrainie w XXI w. rzutują historyczne podziały geopolityczne regionów, w których obecnie pozostało najwięcej ludności polskiego pochodzenia. Istotnym wyróżnikiem polskiej mniejszości narodowej jest jej rozproszenie na dużym obszarze, obejmującym przede wszystkim regiony zachodnie (głównie obwody: lwowski, tarnopolski i rówieński), południowo-zachodnie (obwód czerniowiecki) oraz zachodnio-centralne (obwody: żytomierski, chmielnicki, winnicki, kijowski i miasto Kijów)․․ Wymienione trzy zespoły terytorialne różnią

1 Por. dane ukraińskiego spisu powszechnego z $2001 \mathrm{r}$. na stronie http://www.ukrstat.gov.ua (dostęp: 1 II 2017). 
się XX-wieczną (i dawniejszą) historią. W okresie międzywojennym znalazły się w granicach trzech państw: zachodnie w II Rzeczypospolitej, czerniowiecki (czyli północna Bukowina) w Rumunii, a zachodnio-centralne w Związku Sowieckim. $\mathrm{Na}$ każdym $\mathrm{z}$ tych trzech terytoriów państwowych język polski funkcjonował $\mathrm{w}$ odmiennych warunkach, w kontakcie z różnymi językami (oprócz ukraińskiego z niemieckim, rumuńskim i rosyjskim), co znajduje współcześnie odzwierciedlenie w stanie zachowania i właściwościach lokalnej polszczyzny. Na podział geograficzny nakłada się więc historyczny, kulturowy i polityczny.

Uzasadnienie polityczne ma również przeniesienie w pierwszej połowie XX w. języka polskiego wraz z Polakami z ziem ukraińskich do innych krajów. Na przykład rodowód ukraiński ma mniejszość polska w Kazachstanie, bowiem składa się przede wszystkim z potomków Polaków wysiedlonych podczas stalinowskich deportacji w latach 30. XX w. z sowieckiej części Ukrainy (por. Stroński 1994). Opracowania języka polskiego w Kazachstanie wzbogacają więc wiedzę o historii języka polskiego na dawnych Kresach południowo-wschodnich.

Momentem przełomowym w XX-wiecznej historii Europy był finał II wojny światowej, zaznaczony zmianami granic państwowych oraz przymusowymi migracjami ludności. Szacuje się, że tzw. repatriacja Polaków z Ukrainy - niemal w całości z zachodnich regionów - w nowe granice państwa polskiego objęła po $1945 \mathrm{r}$. ok. 1,5 mln osób (Eberhardt 1994: 174). Wobec tego badania językoznawcze realizowane na ziemiach zachodnich i północnych uwzględniają też przesiedlonych tam Polaków kresowych. Polszczyzna przesiedleńców z dawnych Kresów południowo-wschodnich stała się przedmiotem badań językoznawczych już w latach 50. XX w. (por. Łesiów 1957, 1959). Ten nurt badawczy jest obecny do dzisiaj (por. Zielińska 2013, tamże literatura).

Z położeniem geograficznym wiąże się nie tylko różnica na płaszczyźnie historii, sprzyjających bądź niesprzyjających warunków utrzymania języka polskiego czy specyfiki kontaktów językowych (np. na Bukowinie z językiem rumuńskim). Lokalizacja powoduje również odmienność językową na poziomie wpływu gwar ukraińskich. Mianowicie, wyspowe punkty z językiem polskim są rozsiane na dużym terytorium, odległość między skrajnie zachodnimi i wschodnimi w badanych obwodach zachodnich i zachodnio-centralnych sięga $500 \mathrm{~km}$. Oddziałują więc na nie różniące się między sobą dialekty ukraińskie, głównie naddniestrzański, podolski i wołyński. $\mathrm{Z}$ takiej przyczyny w niektórych regionach notowane są właściwości polszczyzny związane z wpływem miejscowych gwar ukraińskich, niespotykane gdzie indziej. Ilustrację może stanowić protetyczna spółgłoska $v$ - przed nagłosowymi samogłoskami o-, u-, np. vogrut, vobmyła, vusta, vupad, występująca systemowo w kilku polskich gwarach na zachodzie obwodu chmielnickiego. Jest to przykład fonetycznego wpływu ukraińskich gwar zachodniopodolskich na lokalną polszczyznę (Dzięgiel 2003b: 152-153). 


\section{Podział społeczny}

Na ziemiach ukraińskich historycznie ukształtowała się polszczyzna regionalna, odrębna od języka polskiego innych dzielnic I Rzeczypospolitej, różna także od języka polskiego na terenach litewskich i białoruskich. Polszczyzna lwowska (południowokresowa) i wileńska (północnokresowa) wpisywały się w terytorialne zróżnicowanie języka polskiego, które tradycyjnie ujmowano jako odmianę poznańską, krakowską i warszawską (Nitsch 1914). Dzielnicowe odrębności, zwłaszcza leksykalne, zostały uwypuklone w XIX w., gdy w okresie zaborów terytorium I Rzeczypospolitej zostało podzielone między Prusy (Poznań), Austro-Węgry (Kraków i Lwów) i Rosję (Warszawa i Wilno). Istotne zróżnicowanie regionalne polszczyzny w XIX stuleciu podkreślają historycy języka polskiego. Wojciech Ryszard Rzepka, odwołując się do tekstów Stanisława Wasylewskiego - znanego dziennikarza i literata, związanego zarówno ze Lwowem, jak i Poznaniem oraz Opolem - pisze:

Szerokie ich [regionalizmów - E.D.] rozpowszechnienie nadawało polszczyźnie potocznej tak wyraźne zabarwienie regionalne, iż (jak stwierdził S. Wasylewski) już po kilku zaledwie zdaniach można było bez trudu odróżnić „Galileusza” (mieszkańca zaboru austriackiego) od mieszkańca Kongresówki czy Poznaniaka, nie mówiąc już o mieszkańcach Lwowa czy Wilna (Rzepka 1997: 16).

Leksykalne regionalizmy lwowskie czy wileńskie były wyraźnie reprezentowane w słownikach doby nowopolskiej (SL, SWil, SW i SJPD). Jak wykazuje badanie statystyczne przeprowadzone przez Agnieszkę Piotrowską-Wojaczyk, w wymienionych słownikach najwięcej regionalizmów leksykalnych z zaznaczoną lokalizacją geograficzną wywodzi się właśnie z ówczesnych Kresów wschodnich - 1143 jednostki, tj. 54,64\% ogólnego zbioru (Piotrowska-Wojaczyk 2011: 175).

Właściwości regionalne lwowskiej polszczyzny są związane z oddziaływaniem adstratowym i substratowym języka ukraińskiego na gramatykę i słownictwo oraz jej odrębnym rozwojem w warunkach częściowej izolacji od innych regionów. Posługiwały się nią warstwy wykształcone, głównie miejskie, stąd nominacja: kulturalna polszczyzna południowokresowa czy polszczyzna lwowska. Właściwości polszczyzny przedwojennego Lwowa analizowała m.in. Zofia Kurzowa w znanej monografii z lat 80. Koncentrowała się na latach 30. XX w., traktując tę dekadę jako „ostatnie ogniwo w dziejach języka południowokresowego" (Kurzowa 1985/2006: XL).

Ze społecznym rozwarstwieniem języka dużych miast związane były tzw. gwary miejskie, czyli odmiany językowe miejskich warstw niższych. Jak zaznacza cytowany już W.R. Rzepka, odmiany te wykształciły się w wieku XIX w nowych miastach, jak Łódź, a także w starych aglomeracjach miejskich, takich jak Warszawa, Poznań, Kraków i Lwów, w których koncentrowały się różne środowiska i grupy zawodowe (Rzepka 1997: 15). Przedwojennej lwowskiej tzw. gwarze miejskiej poświęciła część wspomnianej monografii Z. Kurzowa, która zrekonstruowała jej cechy na podstawie 
tekstów humorystycznych dialogów radiowych ze Lwowa (Kazimierz Wajda, Henryk Vogelfänger, Szczepko i Tońko. Dialogi radiowe z „Wesołej lwowskiej fali”, nakładem Drukarni Urzędniczej, wyd. we Lwowie w 1934 r.) (Kurzowa 1985/2006: 309-339)².

Poza odmianą wielkomiejską język polski na Ukrainie występuje do dzisiaj w historycznych małych miasteczkach (Mościska, Sambor, Drohobycz i Gródek Podolski) oraz we wsiach. Jak wiadomo, polscy językoznawcy aż do końca lat 8o. XX w. ze względów politycznych nie mogli prowadzić eksploracji na prowincji ukraińskiej (por. Rieger 2012: 12).

Pionierem badań nad powojenną polszczyzną na Wschodzie był Wiaczesław Werenicz z Mińska. Efektem podjętych w latach 60. XX w. przez białoruskiego polonistę i jego zespół prac terenowych jest m.in. dwutomowa publikacja z 1973 r., z tym że językowi polskiemu na ziemiach ukraińskich został w niej poświęcony tylko jeden artykuł (por. Вярэніч 1973)³). Na podstawie zapisów dialektologicznych z tego okresu powstały publikowane później studia o gwarach polskich w okolicach Chmielnickiego na Ukrainie pióra Natalii Ananiewej z zespołu W. Werenicza.

Długofalowe i prowadzone na szeroką skalę badania terenowe na Ukrainie zainicjował na początku lat 9o. XX w. Janusz Rieger. Eksploracje prowadzone przez niego wraz z zespołem (głównie z Iwoną Cechosz-Felczyk i Ewą Dzięgiel), kontynuowane przez E. Dzięgiel, pozwoliły zbadać kilkadziesiąt wsi i miasteczek, w których zachował się język polski. Są to przede wszystkim miejscowości na terenie obwodów: lwowskiego, tarnopolskiego, chmielnickiego i żytomierskiego (częściowe wykazy badanych punktów wraz z mapami podano w publikacjach: Rieger, Cechosz-Felczyk, Dzięgiel 2002: 367, 2007: 341; Dzięgiel 2003b: 173)4.

Osiągnięciem ostatnich dekad są także badania polszczyzny na interesującym językowo i kulturowo pograniczu ukraińsko-rumuńskim, czyli na Bukowinie, rozpoczęte w latach 90. XX w. przez Kazimierza Feleszkę, kontynuowane przez Helenę Krasowską (por. m.in. Krasowska 2006)5.

Przywołane powyżej prace zespołów językoznawców, poświęcone polszczyźnie we wsiach i miasteczkach różnych regionów, przyniosły swego rodzaju odkrycia dotyczące kilku kwestii związanych ze zróżnicowaniem społecznym języka polskiego na ziemiach ukraińskich.

2 O tej szczególnej odmianie przedwojennej polszczyzny lwowskiej pisała Zofia Kurzowa jeszcze w kilku artykułach, por. bibliografia jej prac w: Kurzowa 1985/2006: XX-XXIX.

3 Bibliografia prac W. Werenicza zob. Rieger 2001: 21-27.

4 Na temat współczesnego języka polskiego na Ukrainie powstało pod kierunkiem Janusza Riegera siedem prac doktorskich - pięć opublikowanych (Rudnicki 2000; Cechosz 2001; Dzięgiel 2001; Czarnecka 2014; Zakhutska 2015) i dwie pozostające w maszynopisach (Tymbrowska 2001; Wieczorek 2012). Zestaw ten uzupełnia wydana drukiem rozprawa magisterska (Krawczyk 2007). Bibliografia prac J. Riegera zob.: Wolnicz-Pawłowska, Szulowska 2000: 299-312 oraz Dzięgiel, Czarnecka, Kowalska 2012: 415-423.

5 Bibliografia prac K. Feleszki zob.: Feleszko 2002: 191-200. 
Po pierwsze, zlokalizowano kilkadziesiąt miejscowości z ludnością o polskich korzeniach, w których do czasów współczesnych utrzymał się język polski, w części $\mathrm{z}$ nich bardzo dobrze - we wszystkich pokoleniach, w innych - jedynie u starszych mieszkańców. Są wśród nich nie tylko punkty z zachodniej Ukrainy oraz z Bukowiny, ale też z terenów na wschód od granicy ryskiej, które w międzywojniu znalazły się na terytorium sowieckiej Ukrainy.

Po drugie, ustalono, że polszczyzna w badanych punktach ukształtowała się przede wszystkim w wyniku polskiego osadnictwa na ówczesnych Kresach, głównie chłopskiego i drobnoszlacheckiego, stanowi więc kontynuację języka polskiego przeniesionego z etnicznej Polski. Kwestia genezy języka polskiego zdecydowanie odróżnia terytorium ukraińskie od Litwy i Białorusi. Wspomniany W. Werenicz podkreślał ten podział już na początku lat 9o. XX w.:

Wśród Polaków ukraińskich wybitnie przeważa element etnicznie polski, natomiast na Białorusi i Litwie absolutną większość społeczności polskich składają [stanowią E.D.] potomkowie spolonizowanej ludności białoruskiej lub litewskiej (Werenicz 1992/1996: 125$)^{6}$.

Potwierdzeniem etnicznie polskiego pochodzenia zlokalizowanych na Ukrainie skupisk są nie tylko dane historyczne dotyczące osadnictwa, poświadczają to również opracowania lingwistyczne z zakresu antroponimii i dialektologii, $\mathrm{w}$ tym pionierskie prace na temat kilku przedwojennych gwar polskich w granicach II Rzeczypospolitej (Harhala 1931; Hrabec 1955; Dejna 1956; Łesiów 1957, 1959). Badania dialektologiczne polskich gwar na wschód od Zbrucza oraz na zachodniej Ukrainie, a także na Bukowinie, pozwoliły ustalić utrzymane w nich wyjściowe cechy gwarowe, nieobecne w regionalnej (kulturalnej) polszczyźnie południowokresowej ani w języku ukraińskim. Do takich wyróżników można zaliczyć np. wyraziste polskie właściwości gwarowe występujące w Nowosielicy pod Połonnem: kontynuant dawnego a pochylonego jako o, jak trowa, dziod, czytom, czytosz, czyto itd.; relikty mazurzenia, np. zobocyła, pszeskodzało; końcówki czasownikowe, jak 1 os. lmn. piszema, chodzima; formy czasu przeszłego typu wzion, wzinna, wziny 'wziął, wzięła, wzięli'; formy czasu przeszłego typu robiut, chodziuł; imiesłowy typu zasiote [pole] 'zasiane'. Wymienione cechy pozostają w sprzeczności z ugruntowanym katalogiem właściwości regionalnych (kulturalnych) polszczyzny południowokresowej i przekonują, że gwara Nowosielicy została przeniesiona wraz z osadnikami z etnicznej Polski (więcej w: Dzięgiel 200o, 2003a).

6 Mowa tu o odmiennych proporcjach: na Ukrainie - przewaga ludności etnicznie polskiego pochodzenia (osiedlonej), na Białorusi i Litwie - ludności etnicznie niepolskiej (spolonizowanej). Na temat dyskusji o pochodzeniu języka polskiego na Litwie i Białorusi zob.: Grek-Pabisowa 1992; Maryniakowa 1992; Rieger 1995. 
Po trzecie, opisano podział społeczny i językowy między osadami z populacją polskiego pochodzenia historycznie chłopskimi a drobnoszlacheckimi, głównie na wschód od granicy ryskiej. Podział społeczeństwa na stan chłopski i drobnoszlachecki przestał istnieć w sensie prawnym w XIX w., jednak mentalnie i kulturowo został zachowany w różnych regionach Ukrainy aż do czasów współczesnych (Dzięgiel 2001: 25-26, 178-183, 2003b: 36-43). Te dwie grupy Polaków często określano na dawnych Kresach południowo-wschodnich odmiennymi nazwami: Mazury to ludność chłopska, Lachy - szlachecka, przy czym oba etnonimy uległy pejoratywizacji (więcej zob. Dzięgiel 2013). Mimo łączącej chłopów i drobną szlachtę przynależności do Kościoła rzymskokatolickiego obie warstwy zachowały odrębność obyczajową, kulturową, a także językową. Polskie gwary chłopskie na wschód od Zbrucza wyraźnie się odróżniają nie tylko od regionalnej (kulturalnej) polszczyzny południowokresowej, ale też od języka polskiego nieodległych osiedli szlacheckich, często odznaczają się ponadto niskim prestiżem. Język jest nośnikiem statusu społecznego, $\mathrm{w}$ tym kontekście polskie gwary chłopskie nierzadko stanowiły atrybut stygmatyzacji społecznej, a nawet podwójnej stygmatyzacji, najpierw jako język społeczności wiejskiej, niewykształconej, następnie jako język mniejszości narodowej. Mimo niekorzystnych warunków część z nich utrzymała się do czasów współczesnych.

Przywoływany już W. Werenicz zauważa, że utrzymanie we wsiach chłopskich rodzimego języka przez wiele stuleci (nierzadko od końca XVII w.) w obcym państwie, w innojęzycznym otoczeniu było wynikiem izolacji zarówno od ukraińskiej ludności chłopskiej - ze względu na odmienny język i wyznanie - jak i od rodaków ze stanu szlacheckiego - przez wzgląd na inną pozycję społeczną (Werenicz 1992/1996: 127). Ilustrację tego swoistego konserwatyzmu językowo-kulturowego polskich osad chłopskich może stanowić zaskakująca konstatacja, że jeszcze w latach 9o. XX w. w niektórych miejscowościach nawet na wschód od granicy ryskiej, czyli poza terytorium międzywojennej Rzeczypospolitej, spotykaliśmy starszych respondentów, którzy posługiwali się wyłącznie polską gwarą, nie władali językiem ukraińskim. Lepszą pozycję pod względem prestiżu miał język polski w osadach szlacheckich, był bowiem zbliżony do regionalnej (kulturalnej) polszczyzny południowokresowej, nie oznacza to jednak, że zachował się lepiej.

W ostatnich dekadach coraz wyraźniejsza jest tendencja do zanikania gwar polskich, zwłaszcza na terenach na wschód od Zbrucza, chociaż są także przykłady doceniania miejscowej polszczyzny jako wyróżnika własnej historii i związku z krajem przodków. W pewnym stopniu można porównać tę sytuację do szeroko opisywanego zanikania gwar w różnych regionach Polski, narastającego zwłaszcza od połowy XX w. i związanego z ich niską waloryzacją społeczną. Stąd zgromadzona w ostatnim ćwierćwieczu w kilku ośrodkach (przede wszystkim w Instytucie Języka Polskiego PAN oraz Instytucie Slawistyki PAN) dokumentacja dźwiękowa języka polskiego na Ukrainie stanowi trwały wkład w badania historii języka polskiego za granicą, a także problematyki kontaktów językowych, bilingwizmu i socjolingwistyki. 


\section{Podział ze względu na historię osiedlenia}

Kluczowe kryterium zróżnicowania języka polskiego w miasteczkach i wsiach na Ukrainie stanowi historia osadnictwa polskiego w poszczególnych punktach. Spektakularna różnica w tym względzie zachodzi między miejscowościami, w których Polacy osiedlili się jeszcze w czasach I Rzeczypospolitej, czyli w ostatniej ćwierci XVII i w XVIII w., a tymi, w których osiedlali się pod koniec XIX czy w początkach XX w. Najstarsze badane osady z ludnością polskiego pochodzenia mają metrykę sięgającą 300 lat, najmłodsze - 10o. Wczesna kolonizacja, szczególnie na wschód od Zbrucza, jest związana z wyludnieniem znacznych obszarów Ukrainy w drugiej połowie wieku XVII, w okresie wojny domowej i najazdów turecko-tatarskich, nazywanym w ukraińskiej historiografii Ruina. Na ziemiach ukraińskich były wówczas majątki polskich rodów magnackich - Potockich, Branickich, Czartoryskich, Lubomirskich, Sanguszków - i oni to zasiedlali je ludnością z różnych regionów, sprowadzali również chłopów z etnicznej Polski. Z tak wczesnym polskim osadnictwem mamy do czynienia m.in. na Podolu. Z kolei przypadki późnego osadnictwa - z drugiej połowy XIX w. - są łatwiejsze do jednoznacznego udokumentowania na podstawie źródeł archiwalnych, czasem dostępne są ponadto informacje o terenie wyjściowym osiedleńców. Na Bukowinę północną, jak podaje K. Feleszko (1991: 11-12), Polacy przybyli pod koniec XVIII i w XIX w. Rodowód XIX-wieczny mają również niektóre punkty na Wołyniu, np. wieś Korczunek pod Żytomierzem, do której pierwsze polskie rodziny przybyły w 1884 r., kolejne jeszcze na początku XX w. (por. Rudnicki 2000: 27). Polacy napływali na Ukrainę w XIX w. również jako kadra i robotnicy do rozwijającego się przemysłu. Przykładem takiej migracji jest kolonia na wschodzie kraju w ówczesnym mieście Kamieńskie, późniejszym Dnieprodzierżyńsku, zasiedlona w latach 8o. XIX w. przez Polaków, w tym kadrę inżynieryjno-techniczną i wykwalifikowanych robotników, sprowadzonych do organizowanych wówczas zakładów hutniczych (Krasowska 2012: 74; Швець 2015). O ile w 1896 r. miasto liczyło 18 tys. mieszkańców, to w roku 1913 już 40 407, w tym 14175 Polaków. W międzywojniu skupisko polskie w mieście było na tyle znaczne, że w okresie prowadzenia tzw. polityki korenizacji na sowieckiej Ukrainie, gdy publikowano polskojęzyczne gazety i czasopisma skierowane do mniejszości polskiej, w Kamieńskiem wydawano pismo zakładowe „Dzierżyniec” (1932-1933), przekształcone następnie w "Głos Metalowca” (1933-1935). Był to jedyny polskojęzyczny periodyk o zasięgu lokalnym na wschodzie ówczesnej Ukraińskiej SRS (por. Dzięgiel 2016; Dzięgiel i in. 2016). W mieście powstało jedno $\mathrm{z}$ wyjątkowych skupisk populacji o polskich korzeniach na wschodniej Ukrainie. Sytuację współczesnej, kilkutysięcznej mniejszości polskiej w południowo-wschodnich obwodach kraju wieloaspektowo przedstawiła H. Krasowska (2012, tamże literatura).

7 Dane takie przytaczają - bez podania źródła - Wikipedia (https://ru.wikipedia.org/wiki/Каменское (город) (dostęp: 24 VI 2017)), a także Anna Szweć (Швець 2015). 
Jasne jest, że trwanie wśród innojęzycznej ludności przez kilka stuleci, w izolacji od języka i kultury polskiej, działa na niekorzyść zachowania rodzimego języka, zaś tak dawne oddziaływanie języka ukraińskiego wpływa na proces zapożyczeń gramatycznych i leksykalnych. Dlatego pierwszoplanowym parametrem, który jest uwzględniany np. przy porównaniu skali zapożyczeń w lokalnej polszczyźnie, jest metryka osadnictwa.

Wyznaczenie okresu osiedlenia rzutuje też na kwalifikację właściwości językowych polszczyzny w badanym punkcie. Na przykład na ogół $ł$ (zębowe) w regionalnej (kulturalnej) polszczyźnie lwowskiej opisywane jest jako rodzima cecha archaiczna, utrzymana pod wpływem języka ukraińskiego i rosyjskiego. W historycznej polszczyźnie taka wymowa wycofywała się w XVII w. Inny kontekst interpretacyjny przedstawiają jednak gwary polskie z późnego osadnictwa, jak we wspomnianym Korczunku pod Żytomierzem, w którym pierwotną cechą fonetyczną było $u$ ( $u$ niezgłoskotwórcze), a ł (zębowe) zostało wprowadzone częściowo (u młodszych mieszkańców) pod wpływem języka ukraińskiego i rosyjskiego (Rudnicki 20oo: 161; Rieger, Cechosz-Felczyk, Dzięgiel 2002: 36). W gwarze Korczunka właściwość ta ma więc proweniencję innojęzyczną, a nie rodzimą (o dyskusji na temat archaizmów i interferencji w polszczyźnie południowokresowej zob. Kość 200o; Dzięgiel 2012a).

\section{Podsumowanie}

Z perspektywy ostatniego ćwierćwiecza można mówić o swego rodzaju zwrocie od opracowań regionalnej (kulturalnej) odmiany lwowskiej polszczyzny do badań języka polskiego w miasteczkach i wsiach w różnych regionach Ukrainy. Ta zmiana kierunku była możliwa dzięki przeobrażeniom politycznym - polscy lingwiści mogli podjąć prace terenowe faktycznie dopiero po likwidacji ZSRR (1991 r.). Ważną część nowszych badań stanowią nie tylko prace dialektologiczne czy komparatystyczne, lecz także socjolingwistyczne (np. na temat ewolucji języka polskiej mniejszości, różnic pokoleniowych, identyfikacji narodowej) lub z zakresu bilingwizmu (o bilingwizmie zob. Dzięgiel 2003b: 64-84; o młodzieży polskiego pochodzenia na Ukrainie zob. m.in. Zielińska 2011; Dzięgiel 2012b) ${ }^{8}$. Po ponad dwóch dziesięcioleciach badań terenowych i sukcesywnego wydawania opracowań polszczyzna na Ukrainie jawi się w nowym świetle. Na pierwszy plan wysuwa się jej zróżnicowanie terytorialne, społeczne oraz historyczne, które rzutuje na interpretację zjawisk językowych.

W ostatnich dekadach rozwija się na Ukrainie sieć placówek oświatowych z nauczaniem języka polskiego, kierująca swoją ofertę m.in. do osób polskiego pochodzenia (por. Placówki). Z tej perspektywy istotne stają się opracowania z zakresu

8 Zestawienie publikacji na temat ewolucji języka polskiej mniejszości na Ukrainie, różnic pokoleniowych, identyfikacji narodowej czy bilingwizmu wykracza poza ramy niniejszego artykułu. 
glottodydaktyki polonistycznej, uwzględniające problematykę interferencji językowych polsko-ukraińskich. Aktualność zyskują również badania dydaktyki języka polskiego jako języka przodków (w szerokim rozumieniu angielskiego terminu heritage language akcentującym różnicę między językiem przodków a językiem obcym). Termin heritage language może być odnoszony do opisu sytuacji, w której osoby czy grupy łączy pewien rodzaj więzi z językiem własnej mniejszości narodowej, choć niekoniecznie ten język znająa. Pod uwagę bierze się szerokie spektrum przypadków, od ograniczonej czynnej znajomości języka przodków (np. częściowo mówienia) bądź biernej znajomości (np. po części rozumienia) po sam udział w życiu rodzin czy społeczności, w których język ten jest używany. W tego typu kontekstach język przodków nie jest w ścisłym sensie językiem obcym (dyskusja o terminie heritage language por. np. Peyton, Ranard, McGinnis 2001; w polskiej literaturze glottodydaktycznej por. Lipińska, Seretny 2012). Z kolei nowe kierunki badań glottodydaktycznych i socjolingwistycznych zyskają niewątpliwie na uwzględnieniu dotychczasowej wiedzy o historii i zróżnicowaniu języka polskiego na Ukrainie.

\section{Literatura}

Cechosz I., 2001, Polska gwara Oleszkowiec na Podolu. Fleksja imienna i werbalna, Kraków. CzArneCKA K., 2014, Słowotwórstwo gwar polskich na Ukrainie. Czasownik, Kraków.

Dejna K., 1956, Gwara Milna, „Rozprawy Komisji Językowej Łódzkiego Towarzystwa Naukowego" IV, s. 5-41.

DzIĘGIEL E., 200o, Dawne a pochylone w kilku gwarach południowokresowych, [w:] E. Wolnicz-Pawłowska, W. Szulowska (red.), Kontakty językowe polszczyzny na pograniczu wschodnim. Prace ofiarowane Profesorowi Januszowi Riegerowi, Warszawa, s. 79-88.

DzIĘGIEL E., 2001, Polska gwara wsi Zielonej na Podolu na tle innych gwar południowokresowych. Fleksja imienna $i$ werbalna, Kraków.

DzięGiel E., 2003a, Kresowa gwara Nowosielicy koło Połonnego a gwary w rdzennej Polsce, [w:] E. Wrocławska, J. Zieniukowa (red.), Języki mniejszości i języki regionalne. Pamięci Profesora Zdzisława Stiebera, zasłużonego badacza języków mniejszościowych i pogranicz językowych, w stulecie urodzin, Warszawa, s. 375-388.

DzIĘGIEL E., 2003b, Polszczyzna na Ukrainie. Sytuacja językowa w wybranych wsiach chłopskich i szlacheckich, Warszawa.

DzIĘGIEL E., 2012a, Archaizmy a interferencje w kontaktach języków blisko spokrewnionych (przykład polsko-ukrainski), [w:] „Z Polskich Studiów Slawistycznych”, seria 12, Warszawa, s. 13-19.

DzIĘGIEl E., 2012b, Polacy czy cudzoziemcy? Kształtowanie się identyfikacji narodowej młodzieży polskiego pochodzenia na Ukrainie, [w:] E. Golachowska, A. Zielińska (red.), Konstrukcje i destrukcje tożsamości, t. 2: Tożsamość wobec wielojęzyczności, Warszawa, s. 235-246.

9 Tłumaczenie na język polski terminu heritage language jako język odziedziczony nie jest fortunne w sytuacji, gdy mowa o osobach lub grupach, które już w zasadzie nie znają języka przodków. 
DzIĘGIEL E., 2013, O losach etnonimów Lach $i$ Mazur na dawnych Kresach południowo-wschodnich, [w:] E. Dzięgiel, T. Korpysz (red.), Niejedno ma imię... Prace onomastyczne i dialektologiczne dedykowane Profesor Ewie Wolnicz-Pawłowskiej, Warszawa, s. 117-132.

DzIĘGIEL E. (red.), 2016, Prasa polskojęzyczna w początkach sowietyzacji Ukrainy. Wybór źródet, [on-line:] https://prasapolukr.ijp-pan.krakow.pl/ (dostęp: 24 VI 2017).

Dzięgiel E., Czarnecka K., Kowalska D.A. (red.), 2012, Polskie dziedzictwo językowe na dawnych Kresach. Prace ofiarowane Profesorowi Januszowi Riegerowi, „Język polski dawnych Kresów Wschodnich", t. 5, Warszawa.

DzIĘGIEL E. i in., 2016, Polskojęzyczna prasa na Ukrainie sowieckiej w latach 1918-1939. Przegląd tytułów i treści, Kraków.

Eberhardt P., 1994, Przemiany narodowościowe na Ukrainie XX wieku, „Biblioteka »Obozu«", nr 19, Warszawa.

FELESZKo K., 1991, Język polski na Bukowinie do roku 1945. Zarys problematyki, [w:] J. Rieger, W. Werenicz (red.), Studia nad polszczyzną kresowa, t. 6, Wrocław, s. 7-26.

Feleszko K., 2002, Bukowina moja miłość. Język polski na Bukowinie Karpackiej do 1945 roku, t. 1, red. A. Żor, Warszawa.

GREK-PABISOWA I., 1992, Język polski na kresach pótnocno-wschodnich. Legendy a rzeczywistość, [w:] „Z Polskich Studiów Slawistycznych”, seria 8, Warszawa, s. 55-62.

Harhala W., 1931, Gwara polska okolic Komarna, „Lud Słowiański” II, s. 55-91, 156-177.

Hrabec S., 1955, O polskiej gwarze wsi Duliby w byłym powiecie buczackim, „Rozprawy Komisji Językowej Łódzkiego Towarzystwa Naukowego" III, s. 31-76.

Kość J., 2000, Archaizmy a interferencje w strefie polsko-ukraińskich kontaktów językowych, „Slavia Orientalis” XLIX, z. 3, s. 451-462.

Krasowska H., 2006, Górale polscy na Bukowinie Karpackiej. Studium socjolingwistyczne i leksykalne, Warszawa.

KrasowsKa H., 2012, Mniejszość polska na południowo-wschodniej Ukrainie, Warszawa.

KraWCzy A., 2007, Zapożyczenia leksykalne w sytuacji wielojęzyczności. Ukrainizmy i rusycyzmy w gwarze Maćkowiec na Podolu, Warszawa.

Kurzowa Z., 1985/2006, Polszczyzna Lwowa i Kresów południowo-wschodnich do 1939 roku, [w:] eadem, Prace językoznawcze, t. 1, wybór i oprac. M. Szpiczakowska, M. Skarżyński, Kraków.

Lipińska E., Seretny A., 2012, Między językiem ojczystym a obcym. Nauczanie i uczenie się języka odziedziczonego na przykładzie szkolnictwa polonijnego w Chicago, Kraków.

Łesıów M., 1957, System fonetyczny gwary hutniańskiej, „Rozprawy Komisji Językowej Łódzkiego Towarzystwa Naukowego" V, s. 131-153.

Łesıów M., 1959, Uwagi o fleksji i składni gwary hutniańskiej, „Rozprawy Komisji Językowej Łódzkiego Towarzystwa Naukowego" VI, s. 95-112.

Maryniakowa I., 1992, Pótnocno-wschodnie obszary polszczyzny wobec języków wschodniosłowiańskich i bałtyckich, [w:] „Z Polskich Studiów Slawistycznych”, seria 8, Warszawa, s. $153-158$.

Nitsch K., 1914, Odrębności słownikowe Poznania, Krakowa, Warszawy, „Język Polski” II, S. 261-270.

Peyton J.K., Ranard D.A., McGinnis S. (red.), 2001, Heritage languages in America. Preserving a national resource, Washington.

PiotrowsкA-Wojaczyк A., 2011, Regionalizmy leksykalne w słownikach doby nowopolskiej, Poznań. 
Placów KI: Placówki oświatowe na Ukrainie. Informator, Warszawa 2015.

RIEGER J., 1995, W sprawie genezy i ewolucji polszczyzny w Wielkim Księstwie Litewskim, [w:] idem (red.), Studia nad polszczyzną kresowa, t. 8, Warszawa, s. 31-38.

Rieger J. (red.), 2001, Studia nad polszczyzna kresowa, t. 10, Warszawa.

Rieger J., 2012, Na jubileusz naszych badań nad polszczyzna kresowa, [w:] E. Dzięgiel, K. Czarnecka, D.A. Kowalska (red.), Polskie dziedzictwo językowe na dawnych Kresach. Prace ofiarowane Profesorowi Januszowi Riegerowi, „Język polski dawnych Kresów Wschodnich", t. 5, Warszawa, s. 11-18.

Rieger J., Cechosz-Felczy I., Dzięgiel E., 2002, Język polski na Ukrainie $w$ końcu XX wieku, cz. 1: Stan i status, cechy charakterystyczne. Polszczyzna w Lwowskiem, Tarnopolskiem i na Podolu. Teksty, Warszawa.

Rieger J., Cechosz-Felczy I., DzięGiel E., 2007, Język polski na Ukrainie w końcu XX wieku, cz. 2: Polszczyzna w Lwowskiem, Żytomierskiem i na Podolu. Teksty, Kraków.

Rudnicki S., 2000, Gwara polska wsi Korczunek koło Żytomierza. Fonetyka, fleksja, Warszawa.

RzEPKA W.R., 1997, Rodowód polszczyzny Wielkopolan, [w:] M. Gruchmanowa, B. Walczak (red.), Słownik gwary miejskiej Poznania, Warszawa - Poznań, s. 7-19.

SJPD: W. Doroszewski (red.), Słownik języka polskiego, Warszawa 1958-1969.

SL: S.B. Linde, Słownik języka polskiego, Lwów 1807-1814.

Stroński H., 1994, Polska droga do Kazachstanu, „Przegląd Wschodni” 3, z. 2, s. 145-164.

SW: J. Karłowicz, A.A. Kryński, W. Niedźwiedzki (red.), Słownik języka polskiego, Warszawa 1900-1927.

SWIL: A. Zdanowicz i in. (red.), Słownik języka polskiego, Wilno 1861.

Tyмвrowska G., 2001, Gwara wsi Czerwone Chatki na Żytomierszczyźnie, Instytut Języka Polskiego PAN, rozprawa doktorska.

WERENICZ W., 1992/1996, Uwagi do badań nad polskim dialektem kresowym na Ukrainie, [w:] J. Rieger (red.), Język polski dawnych Kresów Wschodnich, t. 1: Studia i materiały, Warszawa, s. 125-130.

WieCzOreK A., 2012, Słownictwo polskiej gwary kresowej na przykładzie Maćkowiec na Podolu. Charakterystyka funkcjonalna, Uniwersytet Warszawski, rozprawa doktorska.

Wolnicz-Pawıowska E., Szulowska W. (red.), 2000, Kontakty językowe polszczyzny na pograniczu wschodnim. Prace ofiarowane Profesorowi Januszowi Riegerowi, Warszawa.

Zaкнutsка O., 2015, Polszczyzna drobnoszlacheckiej wsi Siaberka na Wołyniu. Słownictwo, Warszawa.

ZielińsKa A., 2013, Mowa pogranicza. Studium o językach i tożsamościach $w$ regionie lubuskim, Warszawa.

ZIELIŃsKa M., 2011, Rola polszczyzny w życiu młodych użytkowników języka polskiego na Ukrainie Zachodniej, „Język, Komunikacja, Informacja” VI, s. 127-134.

Вярэніч В.Л. (ред.), 1973, Польские говоры в СССР, ч. 1-2, Минск.

Швець А.О., 2015, Фонетичні особливості польської мови мешканців Дніпродзержинсь$\kappa a$, „Науковий вісник Міжнародного гуманітарного університету” „Філологія” 19, T. 2, s. 69-72. 


\section{Territorial and societal variants of contemporary Polish in Ukraine Summary}

The article presents various types of differentiation in contemporary Polish language in Ukraine. It focuses primarily on 1) territorial factors - dispersion over a large area and the consequent diversification of political and cultural conditions, as well as influence from different languages and Ukrainian dialects, 2) societal factors - regional (cultural) Polish of former south-eastern Kresy in urban and rural centres, and the stratification of rural Polish into separate dialects of the peasantry and nobility, 3) historical factors - the influence that the history of Polish settlement in the region exerted on the shape of local Polish dialects. Referring to her own, 25-year long experience in studying Polish in Ukraine, and also to the literature on this topic, this author verifies previous views on the territorial and societal variations of the Polish language in Ukraine and revises the related interpretations of linguistic facts (e.g. the origin of the dental $t$ in Polish dialects in Ukraine). 